A N N A L E S

UNIVERSITATIS MARIAE CURIE-SKŁODOWSKA

LUBLIN - POLONIA

VOL. XXXIII

SECTIO FF

2015

\title{
BARBARA BONIECKA
}

Uniwersytet Marii Curie-Skłodowskiej

\section{Co śmieszy dorosłych w kontaktach językowych z dziećmi?}

What amuses adults in language interactions with children?

Kto umie się śmiać, jest panem tego świata.

Verba Volant

Rozwadze poddaję teksty, które powstały jako humorystyczne zupełnie nieświadomie, tak jak badane przez Stanisława Grabiasa w tym aspekcie wypowiedzi studenckie (1968) czy zupełnie przypadkowe polityków analizowane przez Krystynę Warchał (2008), a mimo to stanowiące swoistą grę językową (Buttler 1968, Kępa-Figura 2004). Na warsztat biorę teksty wypowiedziane, a później zapisane. Ich twórcami są małe dzieci. Teksty dziecięce uważane przez dorosłych za komiczne poza radością dają odbiorcy także satysfakcję poznawczą (Tokarz 1991). I właśnie dlatego będę w nich szukać wyznaczników owej ludyczności, chcę ujawnić śmieszne odrębności językowe małego dziecka w stosunku do dorosłego. Gra językowa to przecież, w rozumieniu Ludwika Wittgensteina (2000), zarówno system językowy, jak i każde jego zastosowanie. Źródłem komizmu będą modyfikacje znaków językowych w obrębie samego kodu językowego, a także ich użycie w danym kontekście i sytuacji. Chcę równocześnie pokazać, że te odmienności świadczą o biologicznym i społecznym statusie języka małych użytkowników (Skubalanka 2010).

Oto dwa przykłady żartów telefonicznych, jakie wpadły do głowy Kamilowi (chłopiec sam wykręcił numer i zainicjował rozmowę), dialogów, których intencja rozbawienia nie mogłaby być zrealizowana bez użycia specyficznego narzędzia przekazu - aparatu telefonicznego. Telefon pozbawia nadawcę wzmocnienia 
wypowiedzi gestami i mimiką, odbiorca musi polegać jedynie na tym, co usłyszy. Nadawca nie może sobie pozwolić na takie żartowanie z rozmówcą, jakie byłoby możliwe w rozmowie „twarzą w twarz”.

K: Cześć, to ja.

M: Jaki ja? [niepewnie]

$\mathrm{K}$ : Kubuś. [z poczuciem oczywistości w głosie]

M: Jaki Kubuś? [wyraźnie zdezorientowany]

K: No, Kubuś Puchatek! [radośnie] [Kamil 4;5, Maciej 6;3]

Maciek, rozmówca Kamila, w tym momencie odłożył słuchawkę, sądząc zapewne, że to dziwaczna pomyłka - Kubuś Puchatek to przecież bohater z książki dla dzieci, toteż nie sposób pomyśleć, żeby uczestniczył w dialogu telefonicznym na żywo. Ale już w drugiej bardzo podobnej rozmowie Kamil od razu został rozpoznany przez rozmówczynię ciotkę Lidzię, która, zawsze skłonna do żartów, podchwyciła grę.

K: Cześć!

L: Cześć! Kto mówi?

K: Lew.

L: Lew? A skąd?

$\mathrm{K}: \mathrm{Z}$ lasu.

L: Ale, to pewnie jesteś strasznie dziki?!

$\mathrm{K}$ : Coś ty, ciociu, nie poznałaś mnie? To ja, Kamilek! [Kamil 4;6]

Jak widać, gdy tylko ciotka przejęła inicjatywę, chłopak roztropnie ujawnił swoją tożsamość, unikając dalszych pytań dotyczących lwa, gdyż mogłyby wykazać jego niewiedzę w tym zakresie. Kamil odegrał zaplanowany żart doskonale, przede wszystkim pokazał, że zwierzę może mówić po ludzku przez telefon. Oba żarty wyzyskują tu sytuacje fantastyczne.

A teraz inny przykład pośrednio wyrażanego humoru, tzn. humoru wynikającego z tha sytuacyjnego, niewymagającego uciekania w sferę wyobraźni.

K: Tatusiu, kupić ci coś?

T: Nie, nic mi nie trzeba.

K: Szkoooda. [Kamil 4;6]

Proste na ogół pytanie ma w rzeczywistości głębszy sens. Często w trakcie odwiedzin w gabinecie (lekarskim) taty Kamil dostaje drobne pieniądze na samodzielne zakupy w pobliskim sklepie (najczęściej są to chipsy lub guma do żucia). Czasem też i tacie sprawia coś do jedzenia, gdy ten o to poprosi, co zwykle czyni słowami: Idź do sklepu i kup mi sok pomarańczowy, a za resztę możesz sobie coś kupić. W omawianym przypadku Kamil nie chciał zabiegać o pieniądze dla siebie 
bezpośrednio, licząc na to, że przy okazji zakupów dla ojca sam też skorzysta. Niestety, chociaż intencje jego zostały właściwie odczytane, nie wywołały pożądanego rezultatu. Owo Szkoooda oczywiście może śmieszyć przede wszystkim dorosłego obserwatora zdarzenia, bo to on najsprawniej wychwytuje strategię zastosowaną przez chłopca.

Nie sposób czasem przewidzieć, co dla dziecka może być wielkim przeżyciem i co jest przez swą hiperboliczność odbierane jako żart. Oto dialog, który miał miejsce po powrocie Kamila z kościoła.

K: Mamo, zapłacilem mu, zapłaciłem! [głośno i radośnie]

B: Komu zapłaciłeś?

K: Księdzu!

B: Jak to zapłaciłeś księdzu?

K: No bo tak chodził i mówił „Bóg zapłać”, no to mu zapłaciłem! [Kamil 4;5]

Dosłowne rozumienie przez dziecko słowa zapłacić spowodowało dysonans z pojmowaniem przenośnym, mianowicie $\mathrm{w}$ kościele praktykuje się dawną, tradycyjną formę podziękowania, gdy w języku ogólnym zapłacić oznacza 'dać pieniądze lub rzeczy jako należność (za pracę, towar, usługę)' komuś i w jakiś sposób (Zgółkowa 2004: 313). Chłopiec skojarzył zapewne usługę kościelną w postaci mszy ze zwykłym towarem, za który się płaci na przykład w sklepie.

Bywają jednak takie sytuacje, w których niezaplanowany humor wynika z nieznajomości pewnych słów nazywających nowy dla dziecka przedmiot, ten przedmiot tylko kojarzy się malcowi z innym na zasadzie wspólnoty pewnego elementu.

K: Mamo, jak się nazywa to, gdzieżeśmy byli?

B: To znaczy gdzie?

K: No tam, gdzie są autobusy na szelkach.

B: Aaa, Lublin.

K: Fajnie tam było [z rozmarzeniem]... wieżowce, tyle sklepów. Chciałbym tam jeszcze pojechać.

B: No to jeszcze się kiedyś wybierzemy.

$\mathrm{K}$ : A pojedziemy sobie tym... tym autobusem na szelkach?

B: To się nazywa trolejbus.

K: Trolejbusem? Pliiis. [ang. please]

B: No dobra, pojedziemy.

K: Dziękuję. Jesteś kochaną mamusią, wiesz? [Kamil 4;1]

Podobieństwo pary pałek na dachu pojazdu do szelek (również dwuczęściowych) męskich podtrzymujących spodnie jest nadzwyczaj wyraźne. Zgodność tym bardziej jaskrawa w opisywanej sytuacji, że zestawia się ów pojazd, przedmiot niemałych przecież gabarytów i obsługujący pokaźną liczbę pasażerów, 
z tak przecież prozaicznym i małym jak szelki, wcale nie tak koniecznym w użyciu pewnych osób.

Czasem nadawanie wyrazom obcym polskich form gramatycznych, czyli tworzenie swoistych hybryd językowych sprzyja dowcipowi. Osobie niezorientowanej w pochodzeniu i znaczeniu słowa wydaje się całkowicie niezrozumiałe owo milkiłej.

Mamusiu, bądź taka dobra dla mnie i zrób mi kanapkę z milkiłejem. [z kremem czekoladowym firmy „Milky Way”] [Kamil 4;3]

Zresztą już samo używanie wyrazów obcych, w gruncie rzeczy anglicyzmów, wywołuje w odbiorcy nadspodziewaną radość. Szczególnie w prośbach skierowanych do starszych, prośbach o rzeczy raczej niewskazane, dzieci upodobały sobie słowo please, przy tym często podają je w postaci zreduplikowanej.

Babciu, a zrobisz mi dzisiaj frytki? Pliiis... [ze złożonymi jak do modlitwy rękami] [Kamil $4 ; 5]$

Pójdziemy do Mateusza? Plis plis plis... [Kamil 4;6]

Także zła segmentacja wyrazu w tekście czyniona przez dzieci może wywołać śmiech. Posłużę się przykładem pochodzącym z pracy Edyty ManasterskiejWiącek (2010):

M: To kamera Panasonika. [= firmy Panasonic]

L: To pan Sonik sobie kupił? [Michał 4;5]

Niemal do łez może doprowadzić dziecięca nieumiejętność odróżniania dwóch podobnych brzmieniowo słów, tzw. paronomazji ${ }^{1}$.

Co to są rezerwaty? [mowa w telewizji o prezerwatywach] [Katarzyna 6;3]

Wiadomo, że dzieci (szczególnie w wieku przedszkolnym) mają skłonność do wypowiadania się za pośrednictwem różnych obscenów, radowania się z użycia słów w pewnym stopniu niecenzuralnych, że śmieją się tak samo z własnych „osiągnięć” w tej mierze, jak i z czyichś. Można powiedzieć, że przede wszystkim zainteresowanie słownictwem skatologicznym to znak ich wieku (Simoni-

${ }^{1}$ Takich czysto niezamierzonych językowych żartów jest w języku dzieci mnóstwo. Mam tu na uwadze zanotowane przez Manasterską-Wiącek paronomazje spowodowane pomyleniem m.in. jednej głoski w wyrazie z innymi, z substytucjami głosek, ich redukcją, metatezą, elipsą, także zamianą afiksów itp.: kabarety - gabare(y)ty, linijka - lilijka, Jabłonka - Japonka, smog - cmok, szew - szewc, kondorze - kantorze, amortyzowany - aromatyzowany, a także wielorakie neologizmy oraz neosemantyzmy i kontaminacje w rodzaju zakraplacz w znaczeniu 'kropidło', skrzepa $[k r z e p a+s k r z e p]$. 
des 1976; Cieślikowski 1967). Zadowolenie z poczynionych niżej przez Kamila obserwacji jest nadzwyczaj wyraźne.

K: Babciu, ja już dwa razy w życiu widziałem kro... kro...

I: Krowę?

K: Krowie gówno! [radośnie]

I: Mileczku, każde zwierzę...

K: Robi gówno! I krooowa, i pieees, i nawet człowiek, prawda?

I: Prawda. [Kamil 4;5]

Nie tylko niecenzuralne słowa w tekście mogą przynieść efekt komiczny. Elipsa pewnych słów dialogu, słów nie tyle obscenicznych, co widzianych jako tabu, a za takie czasem uznaje się słownictwo związane z seksem, wywołuje w otoczeniu zażenowane uśmiechy (przykład podaję za Manasterską-Wiącek 2010).

[dziecko podchodzi do ojca w czasie spotkania towarzyskiego i pyta]

$\mathrm{S}$ : Tatusiu, jak się robi syna, na brzuszku czy na boczku?

O: Co? [z zakłopotaniem]

S: No jak się robi syna, na brzuszku czy na boczku, bo zapomniałem!

O: Stefanek, co ty mówisz?

S: No tato, przecież mi pokazywałeś, tylko zapomniałem!

O: Stefanek, co ci pokazywałem?

S: W imię Ojca - na główce, a Syna - na brzuszku. Czy na boczku? [Stefan 3;5] [robienie znaku krzyża]

Z problemami fleksyjnymi wiąże się żart w dialogu matki z synem. Rzecz dotyczy bajki rysunkowej.

P: Dziwne jest w tej twojej bajce, że to krowa i nazywa się Otis. Jak to facet, to byłby byk, a ma wymiona.

M: Bo to krowa. Gadająca.

P: No ale Otis, czyli powinien być byk. A byk gada?

M: A krowa?

P: Ta, tak! [Paweł 8;10]

W polskim systemie fleksyjnym jest zasada, że, z pewnymi wyjątkami, formy rzeczowników męskich kończą się na spółgłoskę, żeńskie natomiast, również z pewnymi wyjątkami, na samogłoskę. Krowa oznacza zwierzę płci żeńskiej i właśnie do niej dobrana powinna być forma imienia. Dziecko zauważa nieścisłość pod tym względem. I to właśnie jego i jego rozmówczynię śmieszy.

A teraz wypowiedź śmiesząca otoczenie, bo mimo że świadcząca o dziecięcym postrzeganiu związków morfologicznych (przykłady pochodzą ze zbiorów Skubalanki 2010), to jednak równocześnie o nieumiejętności wiązania określonych tematów słowotwórczych z formantami. W przypadku płci żeńskiej upraw- 
niona byłaby kompozycja kobieta piekarz, nie zaś derywat sufiksalny pieczar$k a$, tym bardziej że byłby on nazwą grzyba i wyrazem podstawowym (nie zaś pochodnym).

Zobacz, mama, jak ładnie gotuję - ja jestem kucharka. [po chwili]

Zobacz, jak upiekłam ciasto - ja jestem pieczarka. [Natalia 3;0]

Z kolei w tekście:

Ślicznie wyglądasz, jak księżniczka. [matka do córki]

Ja będę modelką, bo się dużo modlę.

ta sama dziewczynka utworzyła derywat, wykorzystując związki homonimiczne między wyrazami, a omijając semantyczne.

Na związkach semantycznych, konkretnie na metaforze, zasadza się humor dialogu ojca z synem.

[ojciec trzyma na ręku synka i pokazuje mu nów księżyca]

O: Patrz, Piotrusiu, jaki rogalik!

P: To nie lodalit, to tsięzić! [Piotr 2;5]

Porównanie księżyca w nowiu do rogalika jest obce tak małemu informatorowi jak Piotruś. Chłopczyk wybiera tu nazwę rogalik jako prototypową dla przedmiotu będącego pieczywem i rezerwuje nazwę księżyc dla obiektu astralnego. „Dzieci - jak piszą uczeni - początkowo przypisują nazwy jedynie [...] do najbardziej typowych odniesień" (Dąbrowska, Kubiński 2005: 114). W tym przykładzie właśnie tak się stało.

Spotyka się pogląd, według którego można wyróżnić dzieci „analityczne” i „holistyczne” (Dąbrowska, Kudliński 2005: 118). Dzieci analityczne zaczynają od pojedynczych wyrazów, następnie łączą je z sobą, dzieci holistyczne natomiast operują pewnymi całościami, które później dzielą na wyrazy i morfemy. Dziecko w cytowanej niżej wypowiedzi naśladuje dwa wyrazy podawane przez matkę i następnie je syntetyzuje, co wywołuje uzasadniony śmiech.

F: A gdzie jest dziadzia?

S: Chyba na cmentarzu.

F: Chyba na pentaziu. [powtarza]

S: Cmen-ta-rzu. Ce jak cytryna.

F: Chyba na pentaziu cytlyna. [Franek 2;5][przykład ze zbioru Skubalanki]

Zmierzając do konkluzji: za główny wyznacznik komizmu (Propp 1977, Dziemidok 1967) uważa się odmienność, odejście od normy, sprzeczność, kontrast, zburzenie porządku i hierarchii itp. W prezentowanych przykładach niezwy- 
kłość dziecięcych wypowiedzi polega na pomieszaniu tego, co wynika z niedosłyszenia, z tym, co dziecko zna od podstaw, na swoistej „, chytrości” i sądzeniu, że inny (słuchacz/odbiorca po prostu) nie wie o wybranej przez dziecko strategii, wreszcie na nieznajomości znaczeń przedstawianych słów.

Należy zwrócić uwagę, że z punktu widzenia niektórych badaczy, dzieci popełniają tu błędy. Uznaję jednak, że z racji nieświadomości tworzenia i bycia w okresie nabywania języka i jego doskonalenia dzieciom nie można zarzucić nieprawidłowości, one nie znają jeszcze wszystkich nieregularności systemowych i komunikacyjnych. Ich wypowiedzi po prostu bawią słuchacza, choć dziecko nie wie, dlaczego.

Śmiech nie grzech - tak każdy powie.

Trzeba śmiać się w szkole, w domu.

Śmiech to radość, śmiech to zdrowie.

Nie zaszkodzi śmiech nikomu.

W. Szwed, Śmiech nie grzech, Białystok 2000

\section{BIBLIOGRAFIA PODMIOTOWA}

Manasterska-Wiącek E., 2010, Myślę, więc rozśmieszam, czyli o komizmie w myśleniu dziecka, „Annales UMCS" Sectio FF, vol. XXVIII, z. 1.

Skubalanka T., 2010, Dziecko i dorosty. Dwa językowe punkty widzenia, „Annales UMCS” Sectio FF, vol. XXVIII, z. 1.

\section{BIBLIOGRAFIA PRZEDMIOTOWA}

Buttler D., 1968, Polski dowcip językowy, Warszawa.

Cieślikowski J., 1967, Wielka zabawa, Wrocław.

Dąbrowska E., Kubiński W., 2005, Procesy dziecięcej akwizycji języka w ujęciu kognitywnym,

[w:] Kardela H., Muszyński Z., Rajewski M. (red.), Kognitywistyka. Problemy i perspektywy, RRR Kogniwistyka I, Lublin.

Dziemidok B., 1967, O komizmie, Warszawa.

Grabias S., 1968, Z zagadnień komizmu w gwarze studenckiej, „Językoznawca”, nr 18-19.

Kępa-Figura D., 2004, Gry językowe w komunikacji radiowej, [w:] Dybalska R., Kępa-Figura D., Nowak P., Przemoc w języku mediów? Analiza semantyczna i pragmatyczna audycji radiowych, Lublin.

Propp W. J., 1977, Problem śmiechu i komizmu, „Przegląd Humanistyczny”, z. 3.

Simonides D., 1976, Wspótczesny folklor stowny dzieci i nastolatków, Warszawa.

Tokarz A., 1991, Poczucie humoru a aktywność twórcza człowieka, „Psychologia Wychowawcza”, $\mathrm{nr} 4$.

Warchał K., 2008, Niezamierzony efekt komiczny jako błąd komunikacyjny, [w:] Kita M. (red.), Btad językowy w perspektywie komunikacyjnej, Katowice.

Wittgenstein L., 2000, Dociekania filozoficzne, thum. B. Wolniewicz, Warszawa.

Zgółkowa H. (red.), 2004, Praktyczny stownik języka polskiego, t. 48, Poznań. 


\section{STRESZCZENIE}

W prezentowanych przykładach niezwykłość dziecięcych wypowiedzi polega na pomieszaniu tego, co wynika z niedosłyszenia, z tym, co dziecko zna od podstaw, na swoistej „,chytrości” i sądzeniu, że inny (słuchacz/odbiorca) nie wie o wybranej przez dziecko strategii, wreszcie na nieznajomości znaczeń przedstawianych słów w użytym przez nie kontekście. Należy zwrócić uwagę, że z punktu widzenia niektórych badaczy, dzieci popełniają tu błędy. Uznaję jednak, że z racji nieświadomości tworzenia i bycia w okresie nabywania języka i jego doskonalenia dzieciom nie można zarzucić nieprawidłowości, one nie znają jeszcze wszystkich nieregularności systemowych i komunikacyjnych. Ich wypowiedzi po prostu bawią słuchacza, choć dziecko nie wie, dlaczego.

Słowa kluczowe: wypowiedzi dziecięce, ludyczność, strategia komunikacyjna, nieregularność systemowa i komunikacyjna

\section{SUMMARY}

In the presented examples, the peculiarity of children's speech consists in mixing of something which results from poor reception, with something the child knows the basics of, in a sort of "cunning" and judging that other (listener/simply the recipient) does not know about the strategy chosen by the child, and finally, the ignorance of meanings of presented words used in the context. It should be noted that from the point of view of some scholars, children make mistakes here. I recognize, however, that because of ignorance of creating and being in a period of language acquisition and improvement, children cannot be accused of irregularities, since they do not yet know all the irregularities and communication system. Their utterances simply amuse the listener, even though the child does not know why.

Key words: children's statements, ludicity, communication strategy, system and communications irregularity 